\title{
Bioinformatics exploration of olive oil: molecular targets and properties of major bioactive constituents
}

\author{
Toluwase Hezekiah Fatoki ${ }^{1, *}$, Cecilia O. Akintayo ${ }^{2}$ and Omodele Ibraheem ${ }^{1}$ \\ ${ }^{1}$ Department of Biochemistry, Federal University Oye-Ekiti, PMB 373 Oye-Ekiti, Ekiti State, Nigeria \\ 2 Department of Industrial Chemistry, Federal University Oye-Ekiti, PMB 373 Oye-Ekiti, Ekiti State, Nigeria
}

Received 18 March 2021 - Accepted 19 May 2021

\begin{abstract}
Olive oil possesses medicinal properties which include antimicrobial, antioxidant and antiinflammatory, anti-diabetes, and anti-cardiovascular diseases. Oleic acid is the most abundant $(95 \%)$ constituent of olive oil and others include linoleic acid, oleuropein, oleanolic acid, maslinic acid, melatonin, and others. The objective of this study is to predict the molecular targets and properties of key bioactive components of olive oil in human. Bioinformatics methods, which involved pharmacokinetics prediction, target prediction and gene network analyses, were used. The results showed that oleic acid has similar targets with linoleic acid, and showed significant probability of binding to several targets such as fatty acidbinding proteins in the adipose, epidermal, liver and muscle as well as alpha, delta and gamma peroxisome proliferator-activated receptors (PPARs). Carbonic anhydrase showed to be the only significant target of tyrosol, while protein-tyrosine phosphatase $1 \mathrm{~B}$, and CD81 antigen were targeted by maslinic acid and oleanolic acid. This study has applauded oleic acid, linoleic acid and tyrosol as olive oil bioactive constituents that have several potential pharmacological effects in humans that modulate several enzymes, receptors and transcription factors. The future work will be to investigate the effects of oleic acid on fatty acid-binding proteins and telomerase reverse transcriptase; melatonin on quinone reductase 2; tyrosol on carbonic anhydrase II; maslinic acid and oleanolic acid on protein-tyrosine phosphatase 1B.
\end{abstract}

Keywords: olive oil / bioinformatics / phytochemical / pharmacokinetics / molecular targets / gene network

Résumé - Exploration bio-informatique de l'huile d'olive: cibles moléculaires et propriétés des principaux constituants bioactifs. L'huile d'olive possède des propriétés médicinales, notamment antimicrobiennes, anti-oxydantes et des effets bénéfiques sur le diabète, l'inflammation et les maladies cardiovasculaires. L'acide oléique est le constituant le plus abondant (95\%) de l'huile d'olive et les autres comprennent l'acide linoléique, l'oleuropéine, l'acide oléanolique, l'acide maslinique, la mélatonine, et d'autres. L'objectif de cette étude est de prédire les cibles moléculaires et les propriétés des composants bioactifs clés de l'huile d'olive chez l'homme. Des méthodes bioinformatiques impliquant la prédiction de la pharmacocinétique, la prédiction des cibles et l'analyse des réseaux de gènes ont été utilisées. Les résultats ont montré que l'acide oléique possède des cibles similaires à celles de l'acide linoléique, et ont montré une probabilité significative de se lier à plusieurs cibles telles que la protéine de liaison des acides gras dans les tissus adipeux, épidermiques, hépatiques et musculaires ainsi que les récepteurs alpha, delta et gamma activés par les proliférateurs de peroxysomes (PPARs). L'anhydrase carbonique s'est révélée être la seule cible significative du tyrosol, tandis que la protéine-tyrosine phosphatase 1B et l'antigène CD81 étaient ciblés par l'acide maslinique et l'acide oléanolique. Cette étude a mis en avant l'acide oléique, l'acide linoléique et le tyrosol en tant que constituants bioactifs de l'huile d'olive qui posséderaient plusieurs effets pharmacologiques potentiels chez l'homme, qui moduleraient plusieurs enzymes, récepteurs et facteurs de transcription. Les travaux futurs consisteront à étudier les effets de l'acide oléique sur les protéines de liaison aux acides gras et la transcriptase inverse de la télomérase ; la mélatonine sur la quinone réductase 2 ; le tyrosol sur l'anhydrase carbonique II ; l'acide maslinique et l'acide oléanolique sur la protéine-tyrosine phosphatase 1B.

Mots clés : huile d'olive / bioinformatique / phytochimie / pharmacocinétique / cibles moléculaires / réseau de gènes

\footnotetext{
*Correspondences: hezekiahfatoki@gmail.com; toluwase.fatoki@fuoye.edu.ng
} 


\section{Introduction}

Olive (Olea europaea L.) is an ancient plant that belongs to the family Oleaceae, which contain about 600 species within 30 genera (Iaria et al., 2016). The genus Olea L. consists of more than 30 species, which are distributed in Africa, Asia, Europe and Oceania, with only Olea europaea subsp. europaea var. europaea being the cultivated olive (Fogher et al., 2010). Olive oil is produced from the olive plant mainly in the Mediterranean basin which produces $90 \%$ of the olive oil consumed worldwide, and it is the principal source of healthy fatty acids, as well as polyphenols and vitamins in minutes (Barbaro et al., 2014; Vasto et al., 2014; Gerber and Hoffman, 2015; Martinez-Gonzalez et al., 2015; Rigacci and Stefani, 2016). Extra virgin olive oil is categorized as a medicinal food because of its nutraceutical benefits and wide range of therapeutic effects such as anti-inflammatory, antioxidant and antimicrobial effect (Cicerale et al., 2012), anti-cardiovascular diseases (Estruch et al., 2006, 2018), diabetes (Salas-Salvado et al., 2011, 2014), neuronal and geriatrics diseases (Khalatbary, 2013; Rodriguez-Morato et al., 2015).

Olive oil contains about $98 \%$ fatty acids, principally oleic acid, and 2\% minor components of over 230 compounds such as squalene, tocopherols, sterols, and polyphenols (PerezJimenez, 2005; Bulotta et al., 2014; Tresserra-Rimbau and Lamuela-Raventos, 2017). Bioactive components of olive oil include oleic acid, tyrosol, hyroxytyrosol, linoleic acid, oleuropein, oleanolic acid, maslinic acid, and melatonin (Segura-Carretero et al., 2010; Fernández-Montesinos et al., 2010; Liu et al., 2010; Bulotta et al., 2014; Tresserra-Rimbau and Lamuela-Raventos, 2017). Extra virgin olive oil contains about 55-83\% oleic acid, and 3.5-21\% linoleic acid (Cocchi et al., 2009), while virgin olive oil contains about $34.5 \mathrm{mg} . \mathrm{L}^{-1}$ tyrosol, $231 \mathrm{mg} \cdot \mathrm{kg}^{-1}$ oleanolic acid, and $172 \mathrm{mg} \cdot \mathrm{kg}^{-1}$ maslinic acid (Perez-Camino and Cert, 1999; Miró-Casas et al., 2001). Oleic acid is the main constituent of olive oil, which is produced by dehydrogenation from stearic acid by stearoyl-ACP desaturase (SACPD) and then desaturated into linoleic acid by FAD2 (Estruch et al., 2018). Melatonin has been found present in olive oil, specifically in the extra virgin types (Fernández-Montesinos et al., 2010; De la Puerta et al., 2007).

The difference between extra virgin olive oil (EVOO) and virgin olive oil (VOO) is that EVOO has a maximum acidity of $0.8 \%$ and may have no defects. VOO can have an acidity up to $2.0 \%$ and has a slight change in taste. Pure olive oils are usually refined olive oils, they are obtained from VOO by refined methods and its free acidity is expressed as less than $0.3 \%$ of oleic acid. For example, the concentration of maslinic acid increases as the olive-oil quality decreases, from values of $38 \mathrm{mg} \cdot \mathrm{kg}^{-1}$ for extra virgin to $227 \mathrm{mg} \cdot \mathrm{kg}^{-1}$ for $9.3 \%$-acidity virgin olive, and to $721 \mathrm{mg} \cdot \mathrm{kg}^{-1}$ for crude pomace olive oils (Perez-Camino and Cert, 1999). However, the differences in the concentration of bioactive compounds in EVOO and VOO will affect their bioavailability at the sites of action.

The genome sequence and functional annotation of (Olea europaea L. subsp. europaea var. europaea cv. "Farga") has resulted in 56349 unique protein coding genes (Cruz et al.,
2016), while that of wild olive tree produced over 50000 protein-coding genes (Unver et al., 2017). Several types of biomarkers such as single nucleotide polymorphisms (SNPs), sequence characterized amplified regions (SCARs) (Fogher et al., 2010), have been used to identify cultivars used in olive oil production (Busconi et al., 2003), and to develop the genetic structure of wild and cultivated olives (Baldoni et al., 2006). Ayed and Rebai (2019) have analyzed 11 Tunisian table olive cultivars based on seven SNP molecular markers (ANTHO3, CALC, FAD2.1, FAD2.3, PAL70, SOD, and SAD.1), to show the possibility of quality authentication and traceability of table olive oil. The functional divergence of oil biosynthesis pathway genes, such as FAD2, SACPD, EAR, and ACPTE, after paralogous event (following duplication), has been responsible for the differential accumulation of oleic and linoleic acids produced in olive when compared with sesame (a closely related oil crop), and the decrease in FAD2 expression and increase in SACPD expression possibly explain the accumulation of exceptionally high levels of oleic acid in olive (Unver et al., 2017).

The impact of dietary olive oil on cancer development have been studied by Zhang et al. (2019), where RNA-sequencing technology and comprehensive bioinformatics analyses were used to elucidate the molecular processes regulated by dietary fat. Differentially expressed genes (DEGs) were identified and were functionally analyzed by gene ontology $(\mathrm{GO})$, kyoto enrichment of genes and genomes(KEGG). Then, proteinprotein interaction(PPI) network and sub-PPI network analyses were conducted using the STRING database and Cytoscape software. The study suggests that a high olive oil diet aggravates cervical cancer progression in vivo and in vitro (Zhang et al., 2019). Diet-gene interactions are studied by the concept of nutrigenetics and nutrigenomics, which identify gene variants associated with different responses to nutrients and the effect of nutrients on the metabolic pathways and homeostatic regulation, respectively (Muller and Kersten, 2003; Ordovas and Mooser, 2004). The objective of this study is to predict the molecular targets and properties of key bioactive components of olive oil in human. This work corroborates the targets which have been experimentally discovered, and it also predicts the novel targets which have not been clinically explored, which may be of medical importance in treatment of certain diseases such as cancer, atherosclerosis, nephrotoxicity, inflammation and skin disorder.

\section{Materials and methods}

\subsection{In Silico target prediction}

The structure of several bioactive compounds of olive oil as listed in literature (Fernández-Montesinos et al., 2010; Liu et al., 2010; Segura-Carretero et al., 2010; Bulotta et al., 2014; Tresserra-Rimbau and Lamuela-Raventos 2017), were obtained from the PubChem compound database in canonical SMILES (simplified molecular input line entry specification) format. The SMILES of each of these compounds were used for in silico prediction of target on the SwissTargetPrediction server, where Homo sapiens was selected as target organism (Diana et al., 2019). 
Table 1. Predicted human protein targets of selected bioactive compounds of olive oil.

\begin{tabular}{|c|c|c|c|c|c|c|c|c|c|}
\hline S.No & \multicolumn{3}{|l|}{ Target } & \multicolumn{6}{|c|}{ Ligands and percentage $(\%)$ probability of binding on targe } \\
\hline 2 & Melatonin receptor $1 \mathrm{~B}$ & MTNR1B & P49286 & & & 100 & & & \\
\hline 3 & Quinone reductase 2 & NQO2 & P16083 & & & 100 & & & \\
\hline 6 & Anandamide amidohydrolase & FAAH & O00519 & & & & & 100 & \\
\hline 7 & Peroxisome proliferator-activated receptor gamma & PPARG & P37231 & 75 & & & & 100 & \\
\hline 8 & Peroxisome proliferator-activated receptor alpha & PPARA & Q07869 & 75 & & & & 100 & \\
\hline 9 & Telomerase reverse transcriptase & TERT & $\mathrm{O} 14746$ & & & & & 100 & \\
\hline 10 & Fatty acid binding protein epidermal & FABP5 & Q01469 & & & & & 100 & \\
\hline 11 & Peroxisome proliferator-activated receptor delta & PPARD & Q03181 & 75 & & & & 100 & \\
\hline 16 & Cyclooxygenase-1 & PTGS1 & P23219 & 50 & & & & & \\
\hline 17 & Carbonic anhydrase II & $\mathrm{CA} 2$ & P00918 & & & & & & 100 \\
\hline 18 & Protein-tyrosine phosphatase $1 \mathrm{~B}$ & PTPN1 & P18031 & & 70 & & 95 & & \\
\hline 19 & DNA polymerase beta & POLB & P06746 & & 45 & & 70 & & \\
\hline 20 & Aldo-keto reductase family 1 member $\mathrm{B} 10$ & AKR1B10 & 060218 & & 55 & & 70 & & \\
\hline 21 & Nuclear receptor ROR-gamma & RORC & P51449 & & 40 & & 60 & & \\
\hline 22 & $\begin{array}{l}\text { Receptor-type tyrosine-protein } \\
\text { phosphatase F (LAR) }\end{array}$ & PTPRF & P10586 & & 40 & & 60 & & \\
\hline 23 & T-cell protein-tyrosine phosphatase & PTPN2 & P17706 & & 40 & & 60 & & \\
\hline 24 & 11-beta-hydroxysteroid dehydrogenase 1 & HSD11B1 & $\mathrm{P} 28845$ & & 60 & & 60 & & \\
\hline 25 & $\begin{array}{l}\text { Low molecular weight phosphotyrosine } \\
\text { protein phosphatase }\end{array}$ & ACP1 & P24666 & & 40 & & 60 & & \\
\hline
\end{tabular}

\subsection{In Silico pharmacokinetics}

Six active ligands (oleic acid, tyrosol, linoleic acid, oleanolic acid, maslinic acid, and melatonin) were selected based on availability of predicted targets in human with a probability of at least $40 \%$ and the SMILES of each of these compounds were used for in silico ADME (absorption, distribution, metabolism, and excretion) screening on SwissADME server (Diana et al., 2017). ADME screening was performed at default parameters.

\subsection{Target gene expression analyses}

Twenty-nine genes were obtained from target prediction results for the six bioactive compounds studied which are MTNR1A, MTNR1B, NQO2, HTR2B, FABP5, FABP4, FABP1, FABP3, FAAH, PPARG, PPARA, PPARD, FFAR1, TERT, SCD, PTGS1, PTPN1, POLB, AKR1B10, RORC, PTPRF, PTPN2, HSD11B1, ACP1, CDC25B, PDE4D, CD81, PLA2G1B, CA2 (full name of these genes are listed in the Tab. 1). These genes ID were compiled and used for expression network analyses (transcription factor enrichment analysis and protein-protein interaction network expansion and kinase enrichment analysis), using eXpression2Kinases (X2K) Web server (Clarke et al., 2018), where human was selected as the background organism.

\section{Results and discussion}

The predicted targets and pharmacokinetics of six active constituents of olive oil (oleic acid, tyrosol, linoleic acid, oleanolic acid, maslinic acid, and melatonin) are shown in Tables 1 and 2. The choice was based on the fact that these six compounds have predicted targets genes in human with a probability of at least $40 \%$ as shown in Table 1 as well as the amount present in the olive oil. Oleic acid which is the main active constituent of olive oil, has six similar targets with linoleic acid, and showed significant probability of binding to several targets such as fatty acid-binding protein in the adipose, epidermal, liver and muscles as well as peroxisome proliferator-activated receptors (alpha, delta and gamma). It has been reported that PPAR-gamma ligands could inhibit 
Table 2. Predicted pharmacokinetics parameters of the selected bioactive compounds of olive oil.

\begin{tabular}{|c|c|c|c|c|c|c|}
\hline Parameters & \multicolumn{6}{|c|}{ Selected bioactive compounds } \\
\hline Molecular weight (g/mol) & 280.45 & 472.7 & 232.28 & 456.7 & 282.46 & 138.16 \\
\hline Heavy atoms (HA) & 20 & 34 & 17 & 33 & 20 & 10 \\
\hline Molar refractivity & 89.46 & 137.82 & 67.18 & 136.65 & 89.94 & 39.4 \\
\hline Total polar surface area $\left(\AA^{2}\right)$ & 37.30 & 77.76 & 54.12 & 57.53 & 37.3 & 40.46 \\
\hline Gastrointestinal absorption & High & High & High & Low & High & High \\
\hline Blood brain barrier (BBB) permeant & Yes & No & Yes & No & No & Yes \\
\hline P-glycoprotein substrate & No & Yes & No & No & No & No \\
\hline Cytochrome P450 inhibitor & CYP1A2, CYP2C9 & - & CYP1A2 & - & CYP1A2, CYP2C9 & - \\
\hline Skin permeation $\log \mathrm{Kp}(\mathrm{cm} / \mathrm{s})$ & -3.05 & -4.56 & -6.59 & -3.77 & -2.6 & -6.84 \\
\hline
\end{tabular}

tumor necrosis factor (TNF)-alpha, interleukin (IL)-6 and IL1-beta expression in monocytes, iNOS, matrix metalloprotease-9(MMP-9) and scavenger receptor-A expression in macrophages among others (Krey et al., 1997).

This in silico work currently supports the hypothesis that exogenous fatty acids (FAs) enter cell nuclei by binding to FABPs. On getting inside the cell, dietary FAs are reversibly bound to lipid-binding proteins, such as FABPs and acyl-CoA binding proteins, such as Acyl-CoA desaturase (Esteves et al., 2016). Dietary omega-3 polyunsaturated fatty acids (PUFAs) downregulate fatty acid-binding protein-4 in the adipocytes in a sex-dependent fashion and also modulate stearoyl-CoA desaturase activity in an age and sex-specific manner (Balogun and Cheema, 2016; Feltham et al., 2019).

Studies have shown that omega-3 PUFAs or oleic acid could activate the expression of transcription factors such as PPAR (Xu et al., 1999; Brunelleschi et al., 2007) and this may have beneficial effects in human inflammatory bowel disease (Dubuquoy et al., 2006). PPAR has been noted for its indispensable involvement in the neurotrophic effect of oleic acid in neurons (Bento-Abreu et al., 2007). Oleic acid has shown a significantly higher glucosyltransferase (GTF) inhibitory activity and antibacterial activity on Streptococcus mutans (Choi et al., 2010). Study has shown that oleate was the most effective down-regulator of FA biosynthesis and cholesterogenesis of various kind of FAs, where it had reduced mRNA abundance, protein level and the activity of both 3-hydroxy-3-methyl-glutaryl CoA (HMG-CoA) reductase and acetyl-CoA carboxylase (Gnoni et al., 2010).

In this study, carbonic anhydrase showed to be the only significant targets of tyrosol, while protein-tyrosine phosphatase $1 \mathrm{~B}$, and CD81 antigen were targeted by maslinic acid and oleanolic acid. Carbonic anhydrase 6, CD209 antigen, and CD44 antigen, have been reported as part of HDL-associated proteins based on the effects of olive oil phenolic compounds (Pedret et al., 2015). Tyrosol is able to inhibit the activation of transcription factors, including NF- $\mathrm{NB}$ and STAT- $1 \alpha$, and expression of inducible nitic oxide synthase(iNOS) and cyclooxygenase-2(COX-2) genes, in cultures of activated macrophages and rat colitis (Moreno, 2003), as well inhibit TNF- $\alpha$ release by LPS-stimulated peripheral blood mononuclear cells isolated from healthy volunteers (Giovannini et al., 2002). Tyrosol also inhibits 5-lipoxygenase, reducing leukotriene B4 and reactive oxygen species (ROS) generation in calcium ionophore-stimulated rat peritoneal leukocytes (De la Puerta et al., 1999). It has been reported that hydroxytyrosol could inhibit human LDL oxidation and platelet aggregation (Morales and Lucas, 2010). Both linoleic and docosahexaenoic acids could cause modulation of gene expression in rat cardiomyocytes (Cheema et al., 2019).

Melatonin receptors are expressed in the tissues of brain (cerebellum and hippocampus), intestine, kidney, and testis. Natural killer (NK) cells, T-lymphocytes, eosinophils, and mast cells possess melatonin receptors (Fatoki et al., 2021). Melatonin could modulate the biological activity and toxicity of tumor necrosis factor- $\alpha$ (TNF- $\alpha)$, increase of interferon- $\gamma$ production (Fernández-Montesinos et al., 2010). Melatonin administration increases the proliferative response of rat lymphocytes, increases the number of NK cells, stimulates the release of pro-inflammatory cytokines interleukin (IL)-1, enhances phagocytosis and modulates apoptosis (Fatoki et al., 2021).

Maslinic acid (2- $\alpha$, 3- $\beta$-dihydroxyolean-12-en-28-oic acid) is a pentacyclic triterpene abundant in the cuticular lipid layer of olive fruits. Maslinic acid has therapeutic properties related to health and disease, including antiinflammatory, antioxidant, antiviral, antihypertensive, and antitumor activities (Fernández-Navarro et al., 2010). Oleanolic acid has been recognized as an PPAR- $\alpha$ agonist (Huang et al., 2005). Oleanolic acid and maslinic acid could modulate the activity of DNA polymerase beta (POLB) and proteintyrosine phosphatase 1B (PTPN1), aldo-keto reductase family 1 member B10 (AKR1B10), nuclear receptor ROR-gamma $\rightarrow$ (RORC), receptor-type tyrosine-protein phosphatase $F$ (LAR) (PTPRF), 11-beta-hydroxysteroid dehydrogenase 1 (HSD11B1) and others as shown in Table 1.

POLB is involved in the homeostasis of the number of cells, DNA repair, inflammatory response and aging process. 


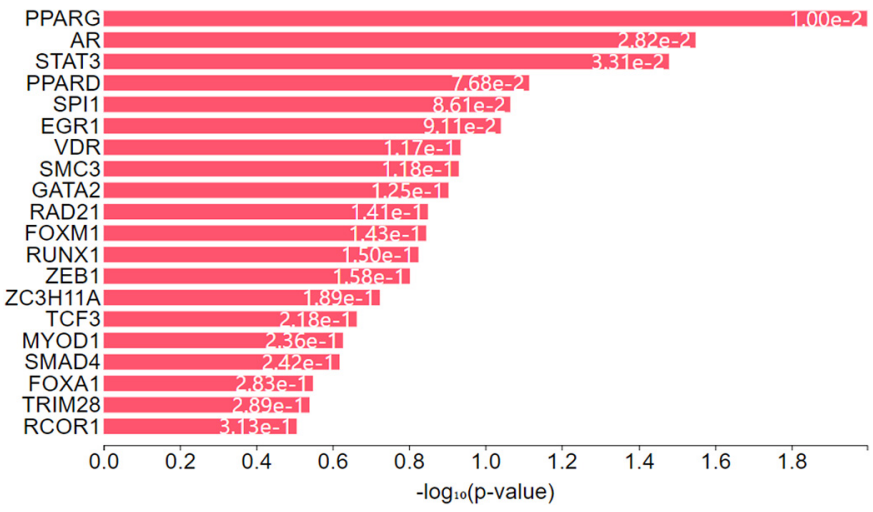

Fig. 1. Transcription factor enrichment analysis. The hypergeometric $p$-value indicates better enrichment.

\section{Transcription factor Intermediate protein - PPI}

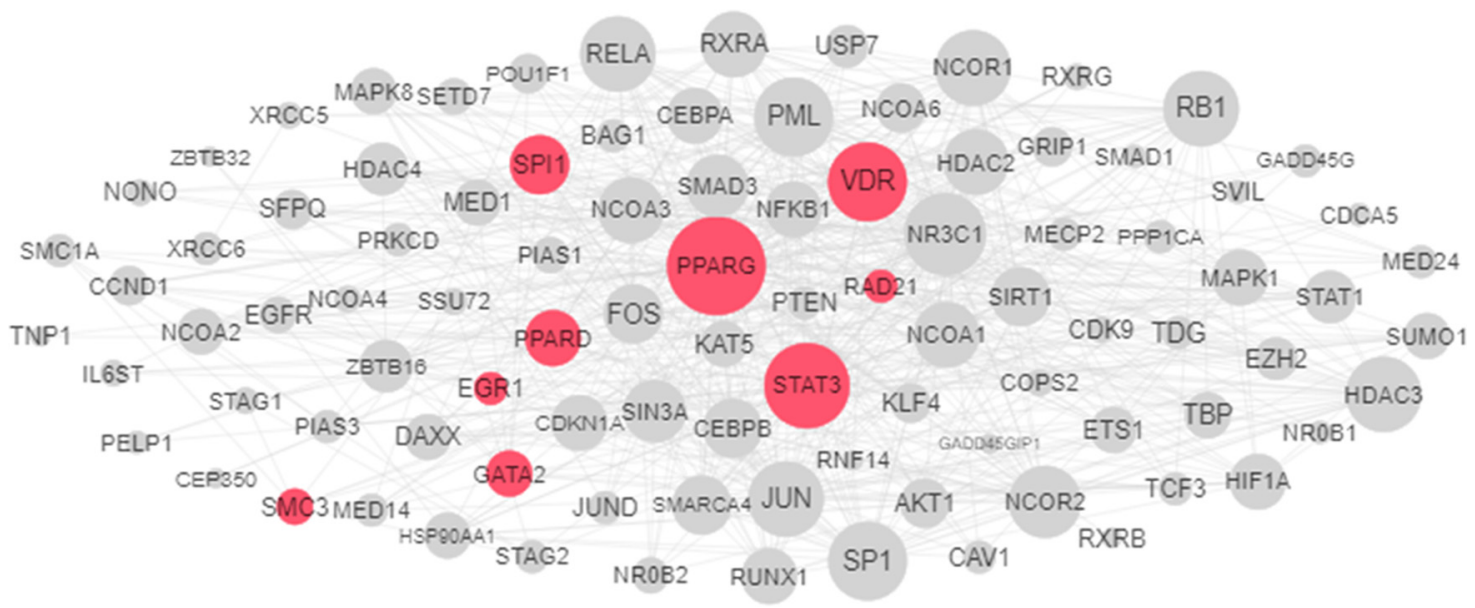

Fig. 2. Protein-protein interaction. The red color and its size indicate highly interacted transcription factors.

PTPN1 is a non-receptor type tyrosine-specific phosphatase that dephosphorylates the receptor protein tyrosine kinases (such as INSR, EGFR, CSF1R, PDGFR) and dephosphorylates the non-receptor protein tyrosine kinases (such as JAK1, JAK2, JAK3, Src family kinases, STAT1, STAT3 and STAT6) either in the nucleus or the cytoplasm. It negatively regulates numerous signaling pathways and biological processes like hematopoiesis, inflammatory response, cell proliferation and differentiation, and glucose homeostasis. PTPN1 plays a multifaceted and important role in the development of the immune system. AKR1B10 is highly expressed in the small intestine, colon and adrenal gland, and plays a critical role in detoxifying dietary and lipid-derived unsaturated carbonyls, and their glutathione-conjugates carbonyls. This protein is involved in the retinol metabolism pathway. Thus, maslinic acid and Oleanolic acid could interfere with retinoid metabolic process. Study has shown that maslinic acid and oleanolic acid significantly reduce hyperlipidemia induced by a highcholesterol diet and lower the expression of the acyl-CoA cholesterol acyltransferase (ACAT) gene (Liu et al., 2010).

As shown in Table 2, oleic acid is moderately soluble, with a high gastrointestinal absorption, serves as an inhibitor for
CYP1A2 and CYP2C9, and has a high bioavailability score. This could justify why oleic acid possesses striking therapeutic effects in the intestine, liver and adipose tissues. Although tyrosol has features closely similar ADME properties to oleic acid, it could permeate the blood-brain barrier (BBB) with no action of the cytochromes and not affected by P-glycoprotein. Tyrosol is bioavailable in humans, even from moderate doses of olive oil consumption with substantial variance among women and men (Covàs et al., 2003). The half-life of tyrosol is estimated to be $2-4 \mathrm{~h}$ in humans (Covàs et al., 2003). Among the six compounds investigated in this study, tyrosol has the highest skin permeability rate, followed by melatonin. Linoleic acid and melatonin could permeate the BBB and have a high gastrointestinal absorption.

This study shows that peroxisome proliferator-activated receptor gamma (PPARG) has the best hypergeometric score as its transcription factor is influenced by the olive oil, followed by AR, STAT3, PPARD, SPI1, EGR1, VDR, and others (Figs. 1 and 2). The kinases that were impacted by the action of olive oil active constituents include CSNK2A1, MAPKs, CDKs, GSKs, ERKs and HIPK2 (Fig. 3). Moreover, major intermediate proteins include HDAC2, HDAC3, 


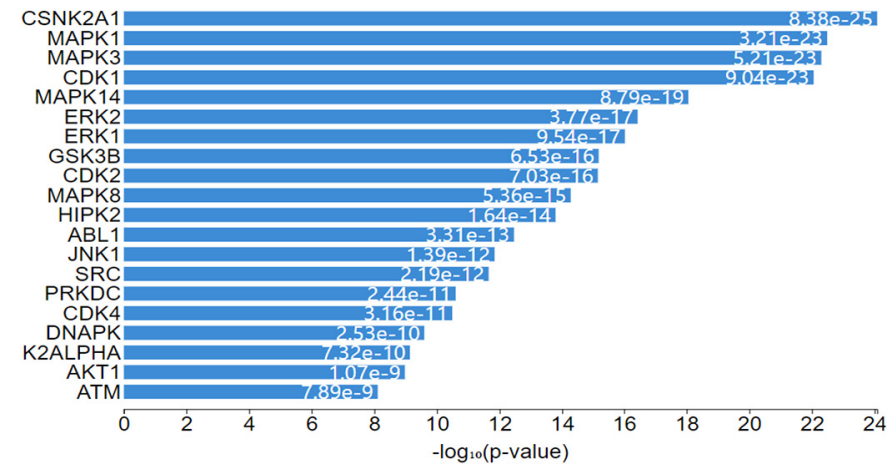

Fig. 3. Kinase enrichment analysis. The hypergeometric $p$-value indicates better enrichment.

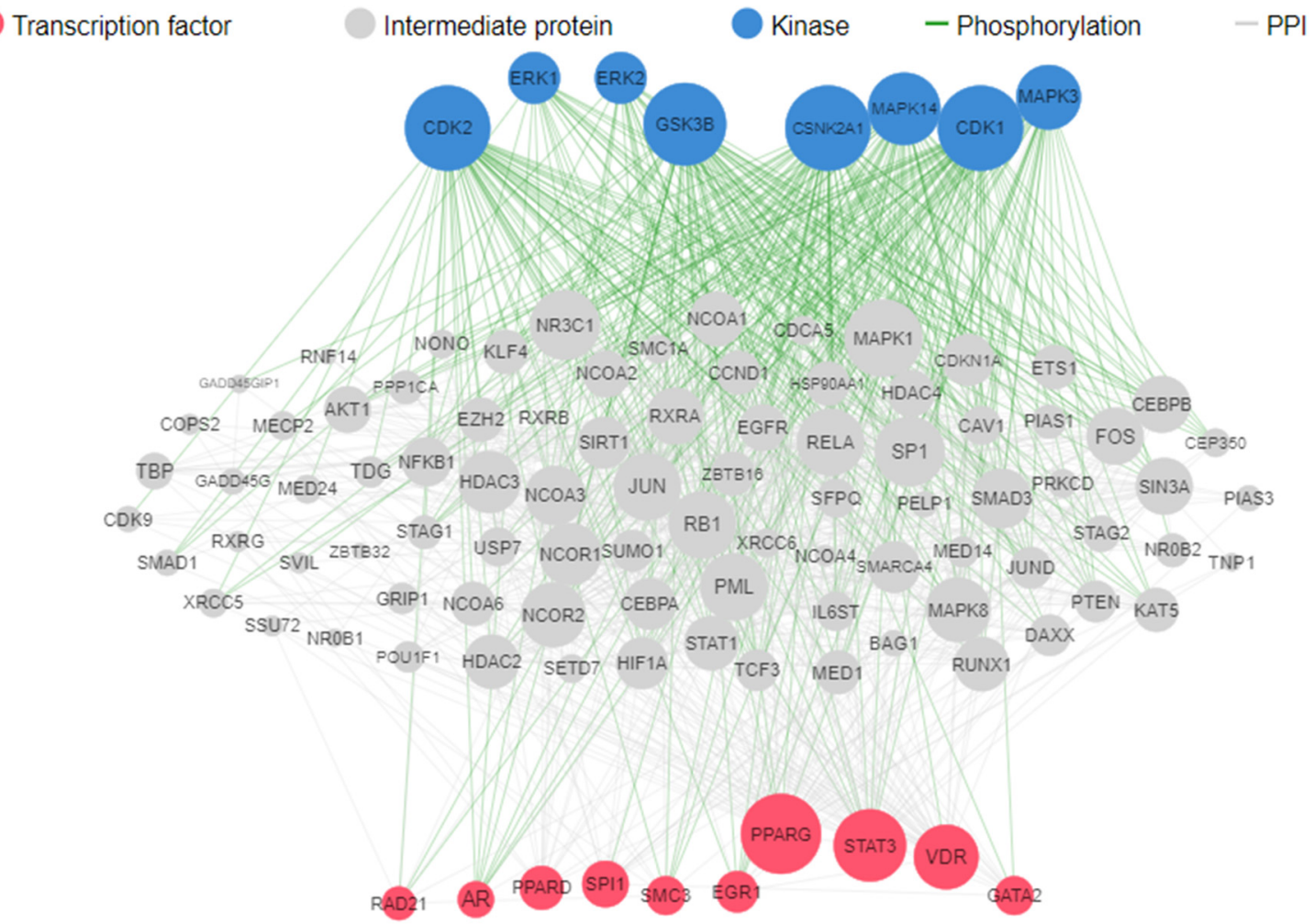

Fig. 4. eXpression2Kinases Network. Showing overall interactions of intermediate proteins, kinases and transcription factors.

SMAD2, SMAD3, NCOA3, PML, RELA, JUN, NCOR1 and others (Fig. 4).

Histone deacetylase 3 (HDAC3), HDAC5, LSD1 (a histone demethylase), Atrophin1, and BCL11A have been reported to interact with TLX to regulate the expression of target genes, and has been validated in human Y79 retinoblastoma cells (Wang and Xiong, 2016). Study has shown that oleic acid triggers hippocampal neurogenesis by binding to TLX/NR2E1 and changes it to a transcriptional activator from a transcriptional repressor of cell cycle and neurogenesis genes (Kandel et al., 2020). Thus, through TLX (orphan nuclear hormone receptor), oleic acid could indirectly activate Wnt7a expression, suppresses the expression of $\mathrm{p} 21$ $v i a$ a p53-dependent mechanism, promotes EGFR signaling in brain cells, and modulates the mitogen-activated protein kinase (MAPK) pathways (Wang and Xiong, 2016) and enhances STAT1 function (Beiting et al., 2015). A bioinformatics study conducted to predict peroxisome proliferatoractivated receptors (PPARs) gene targets on a genome-wide basis, has shown that PPARs could directly regulate some genes such as chromatin remodeling, DNA damage response, Wnt, and mitogen-activated protein kinase (MAPK) (Lemay and Hwang, 2006). FAs and eicosanoids can regulate gene transcription through PPARs (Kliewer et al., 1997; Kersten et al., 2000).

\section{Conclusion}

Knowledge of bioinformatics as it is being applied in lipidomics of a given organism, has not been fully applied to the study of lipids as therapeutics, in order to predict the 
acclaimed medicinal properties. This study has applauded oleic acid, linoleic acid and tyrosol as olive oil bioactive constituents that have several potential pharmacological effects in human by modulating several enzymes, receptors and transcription factors. Moreover, these molecular effects of olive oil indicate its medicinal importance in the treatment of oxidative stress, inflammation, cardiovascular diseases, obesity, diabetes, and age-related diseases. Furthermore, chemical biology and in silico simulation of pharmacological potential of oleic acid (such as molecular docking and dynamics, drugdrug interaction) will yield significant insights to the presently unexplored molecular mechanisms of action to explain the therapeutic effect of olive oil. The future work will be to investigate the effects of oleic acid on fatty acid-binding proteins and telomerase reverse transcriptase; melatonin on quinone reductase 2; tyrosol on carbonic anhydrase II; maslinic acid and oleanolic acid on protein-tyrosine phosphatase 1B.

Conflicts of interest. The authors declare no conflicts of interest.

\section{References}

Ayed RB, Rebai A. 2019. Tunisian table olive oil traceability and quality using SNP genotyping and bioinformatics Tools. BioMed Res Int 2019: 1-9, Article ID 8291341. https://doi.org/10.1155/ 2019/8291341.

Baldoni L, Tosti N, Ricciolini C, et al. 2006. Genetic structure of wild and cultivated olives in the central Mediterranean basin. Ann Bot 98: 935-942.

Balogun KA, Cheema SK. 2016. Dietary omega-3 polyunsaturated fatty acids reduced adipocyte hypertrophy by downregulating acyl-CoA:diacylglycerol acyltransferase- 2 and fatty acids binding protein-4 in a sex dependent fashion. Lipids 51(1): 25-38.

Barbaro BG, Toietta G, Maggio R, et al. 2014. Effects of the olivederived polyphenol oleuropein on human health. Int J Mol Sci 15 (10): 18508-18524.

Beiting DP, Hidano S, Baggs JE, et al. 2015. The orphan nuclear receptor TLX is an enhancer of STAT1-Mediated transcription and immunity to Toxoplasma gondii. PLoS Biol 13(7): e1002200.

Bento-Abreu A, Tabernero A, Medina JM. 2007. Peroxisome proliferator-activated receptor-alpha is required for the neurotrophic effect of oleic acid in neurons. J Neurochem 103: 871881.

Brunelleschi S, Bardelli C, Amoruso A, et al. 2007. Minor polar compounds extra-virgin olive oil extract (MPC-OOE) inhibits NF-kappa B translocation in human monocyte/macrophages. Pharmacol Res 56: 542-549.

Bulotta S, Celano M, Lepore SM, Montalcini T, Puija A, Russo D. 2014. Beneficial effects of the olive oil phenolics components oleuropein and hydroxytyrosol: Focus on protection against cardiovascular and metabolic diseases. J Transl Med 219: 2-9.

Busconi M, Foroni C, Corradi M, Bongiorni C, Cattapan F, Fogher C. 2003. DNA extraction from olive oil and its use in the identification of the production cultivar. Food Chem 83: 127-134.

Cheema SK, Tappia PS, Dhalla NS. 2019. Modification of gene expression in rat cardiomyocytes by linoleic and docosahexaenoic acids. Can J Phys Pharmacol 97(4): 320-327.

Choi S-G, Won S-R, Rhee H-I. 2010. Oleic acid and inhibition of glucosyltransferase. In: Preedy VR, Watson RR, eds. Olives and olive oil in health and disease prevention. Elsevier Inc., pp. 13751383.

Cicerale S, Lucas LJ, Keast RS. 2012. Antimicrobial, antioxidant and anti-inflammatory phenolic activities in extra virgin olive oil. Curr Opin Biotechnol 23(2): 129-135.

Clarke DJB, Kuleshov MV, Schilder BM, et al. 2018. eXpression2Kinases (X2K) Web: linking expression signatures to upstream cell signaling networks. Nucl Acids Res 46(W1): 171-179.

Cocchi M, Tonello L, Martínez ÁJ, Lercker G, Caramia GM. 2009. Extra virgin olive oil and oleic acid. Nutr Clín Diet Hosp 29(3): 12-24.

Covàs MI, Miró-Casas E, Fitó M, et al. 2003. Bioavailability of tyrosol, an antioxidant phenolic compound present in wine and olive oil, in humans. Drugs Exp Clin Res 29: 203-206.

Cruz F, Julca I, Gómez-Garrido J, et al. 2016. Genome sequence of the olive tree, Olea europaea. GigaScience 5: 29. https://doi.org/ 10.1186/s13742-016-0134-5.

De la Puerta R, Ruiz-Gutierrez V, Hoult JRS. 1999. Inhibition of leukocyte 5-lipoxygenase by phenolics from virgin olive oil. Biochem Pharmacol 57: 445-449.

De la Puerta C, Carrascosa-Salmoral MP, Garcia-Luna PP, et al. 2007. Melatonin is a phytochemical in olive oil. Food Chem 104: 609612.

Diana A, Michielin O, Zoete V. 2017. SwissADME: A free web tool to evaluate pharmacokinetics, druglikeness and medicinal chemistry friendliness of small molecules. Sci Rep 7: 42717.

Diana A, Michielin O, Zoete V. 2019. SwissTargetPrediction: Updated data and new features for efficient prediction of protein targets of small molecules. Nucl Acids Res 1-8. https://doi.org/ 10.1093/nar/gkz382.

Dubuquoy L, Rousseaux C, Thuru X, et al. 2006. PPARgamma as a new therapeutic target in inflammatory bowel diseases. Gut 55: 1341-1349.

Esteves A, Knoll-Gellida A, Canclini L, Silvarrey MC, André M, Babin PJ. 2016. Fatty acid binding proteins have the potential to channel dietary fatty acids into enterocyte nuclei. J Lipid Res 57: 219-232.

Estruch R, Martinez-Gonzalez MA, Corella D, et al. 2006. Effects of a Mediterranean-style diet on cardiovascular risk factors: A randomized trial. Ann Intern Med 145(1): 1-11.

Estruch R, Ros E, Salas-Salvadó J, et al. 2018. Primary prevention of cardiovascular disease with a mediterranean diet supplemented with extra-virgin olive oil or nuts. $N$ Engl J Med 378(25): e34.

Fatoki TH, Ibraheem O, Adeseko CJ, et al. 2021. Melanogenesis, its regulatory process, and insights on biomedical, biotechnological, and pharmacological potentials of melanin as antiviral biochemical. Biointerf Res Appl Chem 11(4): 11969-11984.

Feltham BA, Balogun KA, Cheema SK. 2019. Omega-3 polyunsaturated fatty acids have an age and sex specific effect to regulate stearoyl-CoA desaturase-1 and myelin basi protein in the cerebellum of C57BL/6 mice. Pros Leuk Essent Fatty Acids 148: 16-24.

Fernández-Montesinos R, De la Puerta C, García-Luna PP, Reiter RJ, Pozo D. 2010. The occurrence of the biogenic amine melatonin in olive oil: Implications in health and disease prevention. In: Preedy VR, Watson RR, eds. Olives and olive oil in health and disease prevention. Elsevier Inc., pp. 275-282.

Fernández-Navarro M, Peragón J, Esteban FJ, Amores V, de la Higuera M, Lupiáñez JA. 2010. Maslinic acid: A component of olive oil on growth and protein-turnover rates. In: Preedy VR, Watson RR, eds. Olives and olive oil in health and disease prevention. Elsevier Inc., pp. 1415-1421. 
Fogher C, Busconi M, Sebastiani L, Bracci T. 2010. Olive genomics. In: Olives and olive oil in health and disease prevention. Elsevier Inc., pp. 17-24.

Gerber M, Hoffman R. 2015. The Mediterranean diet: Health, science and society. Br J Nutr 113(Suppl 2): S4-10.

Giovannini L, Migliori M, Filippi C, et al. 2002. Inhibitory activity of the white wine compounds, tyrosol and caffeic acid, on lipopolysaccharide-induced tumor necrosis factor-alpha release in human peripheral blood mononuclear cells. Int $J$ Tissue React 24: $53-56$.

Gnoni GV, Natali F, Geelen MJH, Siculella L. 2010. Oleic acid as an inhibitor of fatty acid and cholesterol synthesis. In: Preedy VR, Watson RR, eds. Olives and olive oil in health and disease prevention. Elsevier Inc., pp. 1365-1373.

Huang TH, Peng G, Kota BP, et al. 2005. Pomegranate flower improves cardiac lipid metabolism in a diabetic rat model: role of lowering circulating lipids. Br J Pharmacol 145: 767-774.

Iaria DL, Chiappetta A, Muzzalupo I. 2016. A de novo transcriptomic approach to identify flavonoids and anthocyanins "switch-off" in olive (Olea europaea L.) drupes at different stages of maturation. Front Plant Sci 6: 1246.

Kandel P, Semerci F, Bajic A, et al. 2020. Oleic acid triggers hippocampal neurogenesis by binding to TLX/NR2E1. bioRxiv preprint $1-18$.

Kersten S, Desvergne B, Wahli W. 2000. Roles of PPARs in health and disease. Nature 405: 421-424.

Khalatbary AR. 2013. Olive oil phenols and neuroprotection. Nutr Neurosci 16(6): 243-249.

Kliewer SA, Sundseth SS, Jones SA, et al. 1997. Fatty acids and eicosanoids regulate gene expression through direct interactions with peroxisome proliferator-activated receptor alpha and gamma. Proc Natl Acad Sci USA 94: 4318-4323.

Krey G, Braissant O, L'Horset F, et al. 1997. Fatty acids, eicosanoids, and hypolipidemic agents identified as ligands of peroxisome proliferator-activated receptors by coactivator-dependent receptor ligand assay. Mol Endocrinol 11: 779-791.

Lemay DG, Hwang DH. 2006. Genome-wide identification of peroxisome proliferator response elements using integrated computational genomics. J Lipid Res 47: 1583-7.

Liu J, Rajendram R, Zhang L. 2010. Effects of oleanolic acid and maslinic acid on glucose and lipid metabolism: Implications for the beneficial effects of olive oil on health. In: Preedy VR, Watson $\mathrm{RR}$, eds. Olives and olive oil in health and disease prevention. Elsevier Inc., pp. 1423-1429.

Martinez-Gonzalez MA, Salas-Salvado J, Estruch R, et al. 2015. Benefits of the Mediterranean diet: insights from the PREDIMED Study. Progr Cardiovasc Diseases 58: 50-60.

Miró-Casas E, Farré-Albaladejo M, Covàs MI, et al. 2001. Capillary gas chromatography-mass spectrometry quantitative determination of hydroxytyrosol and tyrosol in human urine after olive oil intake. Anal Biochem 294: 63-72.

Morales JC, Lucas R. 2010. Structure-activity relationship of phenolic antioxidants and olive components. In: Preedy VR, Watson RR, eds. Olives and olive oil in health and disease prevention. Elsevier Inc., pp. 905-914.
Moreno JJ. 2003. Effect of olive oil minor components on oxidative stress and arachidonic acid mobilization and metabolism by macrophages RAW 264.7. Free Radic Biol Med 35: 1073-1081.

Muller M, Kersten S. 2003. Nutrigenomics: Goals and strategies. Nat Rev Genet 4: 315-322.

Ordovas JM, Mooser V. 2004. Nutrigenomics and nutrigenetics. Curr Opin Lipidol 15: 101-108.

Pedret A, Catalán Ú, Fernández-Castillejo S, et al. 2015. Impact of virgin olive oil and phenol-enriched virgin olive oils on the HDL proteome in hypercholesterolemic subjects: A double blind, randomized, controlled, cross-over clinical trial (VOHF Study). PLoS ONE 10(6): e0129160.

Perez-Camino MC, Cert A. 1999. Quantitative determination of hydroxyl pentacyclic triterpene acids in vegetable oils. J Agric Food Chem 47: 1558-1562.

Perez-Jimenez F. 2005. International conference on the healthy effect of virgin olive oil. Eur J Clin Invest 35: 421-424.

Rigacci S, Stefani M. 2016. Nutraceutical properties of olive oil polyphenols. An itinerary from cultured cells through animal models to humans. Int J Mol Sci 17(6): 843.

Rodriguez-Morato J, Xicota L, Fito M, et al. 2015. Potential role of olive oil phenolic compounds in the prevention of neurodegenerative diseases. Molecules 20(3): 4655-4680.

Salas-Salvado J, Bulló M, Babio N, et al. 2011. Reduction in the incidence of type 2 diabetes with the Mediterranean diet: results of the PREDIMED-Reus nutrition intervention randomized trial. Diabetes Care 34(1): 14-19.

Salas-Salvado J, Bullo N, Estruch R, et al. 2014. Prevention of diabetes with Mediterranean diets: A subgroup analysis of a randomized trial. Ann Intern Med 160(1): 1-10.

Segura-Carretero A, Menéndez-Menéndez J, Fernández-Gutiérrez A. 2010. Polyphenols in olive oil: the importance of phenolic compounds in the chemical composition of olive oil. In: Preedy VR, Watson RR, eds. Olives and olive oil in health and disease prevention. Elsevier Inc., pp. 167-175.

Tresserra-Rimbau A, Lamuela-Raventos RM. 2017. Olives and olive oil: A Mediterranean source of polyphenols. In: Kiritsakis A, Shahidi F, eds. Olives and olive oil as functional foods: Bioactivity, chemistry and processing, 1st ed. John Wiley \& Sons Ltd, pp. 417-428.

Unver T, Wu Z, Sterck L, et al. 2017. Genome of wild olive and the evolution of oil biosynthesis. PNAS E9413-E9422. https://doi. org/10.1073/pnas.1708621114.

Vasto S, Barera A, Rizzo C, et al. 2014. Mediterranean diet and longevity: An example of nutraceuticals? Curr Vasc Pharmacol 12(5): 735-738.

Wang T, Xiong J-Q. 2016. The orphan nuclear receptor TLX/NR2E1 in neural stem cells and diseases. Neurosci Bull 32(1): 108-114.

$\mathrm{Xu}$ HE, Lambert MH, Montana VG, et al. 1999. Molecular recognition of fatty acids by peroxisome proliferator-activated receptors. Mol Cell 3: 397-403.

Zhang X, Yang P, Luo X, et al. 2019. High olive oil diets enhance cervical tumour growth in mice: transcriptome analysis for potential candidate genes and pathways. Lipids in Health and Disease 18: 76.

Cite this article as: Fatoki TH, Akintayo CO, Ibraheem O. 2021. Bioinformatics exploration of olive oil: molecular targets and properties of major bioactive constituents. OCL 28: 36 . 